\title{
Linguaggi architettonici ed esoterici per la rappresentazione della Quinta da Regaleira a Sintra
}

\author{
Gennaro Pio Lento \\ Fabiana Guerriero \\ Luigi Corniello \\ Pedro António Janeiro
}

Abstract

\begin{abstract}
La ricerca è incentrata sull'analisi inedita della Quinta da Regaleira, ubicata nel cuore del sito Unesco di Sintra, ponendo l'attenzione sulle peculiarità della duplice componente architettonica: epigea, simboleggiante il paradiso, che si sviluppa seguendo l'andamento della collina, e ipogea la quale, con percorsi nel sottosuolo, rimanda all'inferno dantesco. Si materializza, con questi scenari un viaggio iniziatico, quale peregrinatio vera mundi, per un giardino simbolico ricco di riferimenti alla mitologia, all'epica virgiliana, alla missione templare dell'Ordine di Cristo e all'alchimia.

Lo studio è stato caratterizzato da una preventiva analisi della bibliografia esistente, principalmente orientata alla narrazione storica e simbolica del Parco, e delle fonti grafiche dell'architetto italiano Luigi Manini. L'attività di rilievo è stata svolta utilizzando metodologie consolidate della disciplina, attuate attraverso attività di tipo strumentale e mediante la modellazione e la visualizzazione interattiva digitale tramite filmati sviluppati con software innovativi. Gli elaborati prodotti costituiscono, oltre a una innovativa banca dati interattiva e digitale grafica e iconografica, un riferimento simbolico delle architetture presenti all'interno della Quinta da Regaleira che l'hanno resa celebre attirando ogni anno milioni di visitatori.
\end{abstract}

Parole chiave

rilievo, drone, modellazione, Sintra, UNESCO.

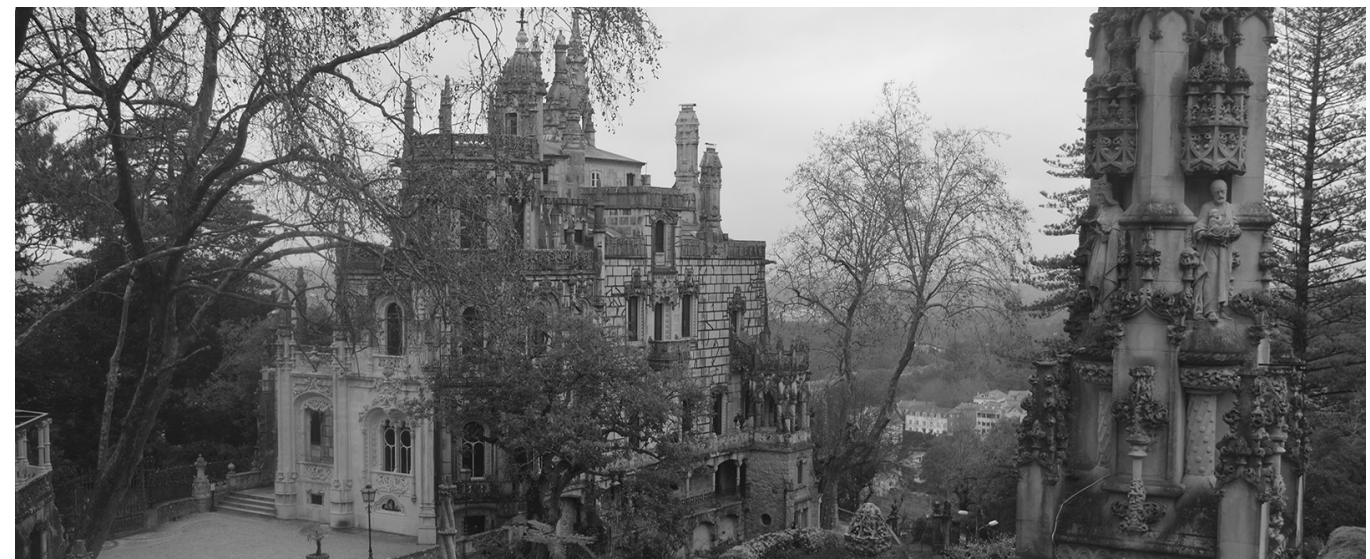




\section{Introduzione}

La Quinta da Regaleira, enigmatico complesso architettonico e vegetazionale di assoluto pregio e fascino, è parte delle bellezze che caratterizzano il territorio portoghese. La città collinare di Sintra, che accoglie la tenuta, è stata riconosciuta nel 1995, durante la diciannovesima sessione del Comitato del Patrimonio Mondiale dell'Unesco tenutasi a Berlino, come Patrimonio dell'Umanità, dando il via alla definizione della categoria "Paesaggio Culturale" da parte dell'Unesco.

Lo studio inedito del sistema architettonico epigeo ed ipogeo, nonché del grande giardino condotto attraverso il rilievo manuale e strumentale, inteso come strumento di ricerca scientifica finalizzata alla conoscenza ed alla conservazione del patrimonio, ne ha delineato le interessanti caratteristiche architettoniche e strutturali ponendo l'attenzione sul linguaggio simbolico adottato dal genio creativo dell'architetto e scenografo italiano Luigi Manini e la possibile lettura in chiave esoterica che gli si può attribuire offrendo, inoltre, la possibilità di consultare nuove fonti per eventuali interventi futuri aventi come obiettivo quello di preservare il ricco valore patrimoniale del sito Unesco, ma anche la valorizzazione e la fruizione a beneficio dei posteri.

Fig. I. La Quinta da Regaleira a Sintra planimetria generale.

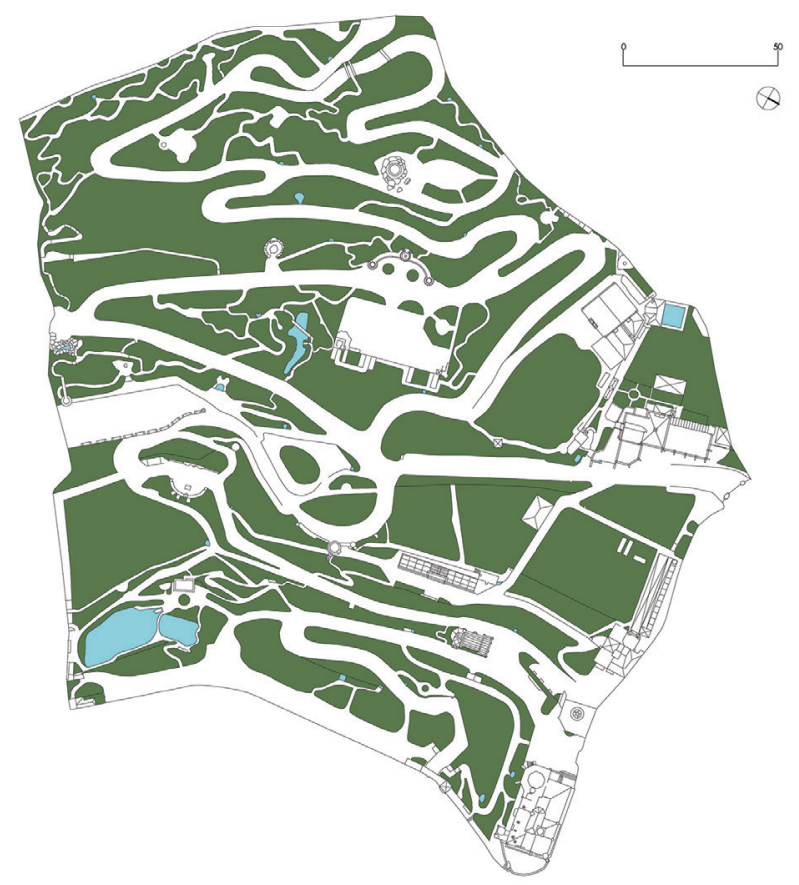

Simboli e strutture nella Quinta da Regaleira

A pochi chilometri da Lisbona, nel cuore della città di Sintra, si erge la Quinta da Regaleira, suggestivo esempio di compenetrazione tra architettura e sistema vegetazionale appartenente alla tradizione dei grandi giardini europei ricoprendo, infatti, ben quattro ettari di terreno alle pendici della catena montuosa della Serra. II Parco, appartenuto nel corso dei secoli a diversi proprietari tra i quali la baronessa di Regaleira da cui trae il nome, deve il suo aspetto attuale al facoltoso ed eccentrico entomologo, commerciante di caffè, nonché massone brasiliano-portoghese Antonio Augusto de Carvalho Monteiro che acquisì la tenuta negli ultimi anni dell'800. Insoddisfatto del progetto, in stile medioevale consegnato dall'architetto francese Henri Lusseau, il ricco proprietario commissionò nel I 898 l'intera opera di riammodernamento della tenuta all'architetto e scenografo italiano Luigi Manini allo scopo 
di vedere realizzato il suo sogno di una dimora capace di manifestare adeguatamente, oltre che le ingenti ricchezze accumulate in Brasile, il suo personale e complesso universo culturale. II Manini, abituato ad adattare le sue capacità alle richieste dei committenti, accolse con entusiasmo la sfida e la considerò un'occasione per sfuggire alla sterile riproposizione di modelli architettonici dell'epoca. L'opportunità fu quella di mettere alla prova la sua anima romantica di pittore e creatore di paesaggi fantastici, rivisitando in una nuova chiave il neomanuelino. L'architetto italiano si occupò inizialmente del progetto dell'imponente residenza, posizionandola ai piedi della tenuta verdeggiante. Il primo progetto per il Palazzo della Regaleira venne però accantonato a favore di un successivo disegno meno ambizioso, in cui gli spazi di distribuzione, notevolmente ridimensionati, si addensano lungo l'asse centrale del rettangolo che costituisce l'impianto dell'edificio. I prospetti esterni adornati da contrafforti, pinnacoli e portici, sono caratterizzati dalla fusione di diversi stili, tra cui il neomaunelino, il gotico e il rinascimentale con importanti riferimenti esoterici e alchemici.

Nel giardino caratterizzato da infinite tonalità di verde che circonda il Palazzo e al quale l'architettura aspira a fondersi, trovano posto diversi manufatti atti ad accogliere differenti funzioni, in accordo con gli stili utilizzati ma di minori dimensioni, quali: una cappella, una serra, una casa del generatore e delle scuderie.

Fig. 2. La Quinta da

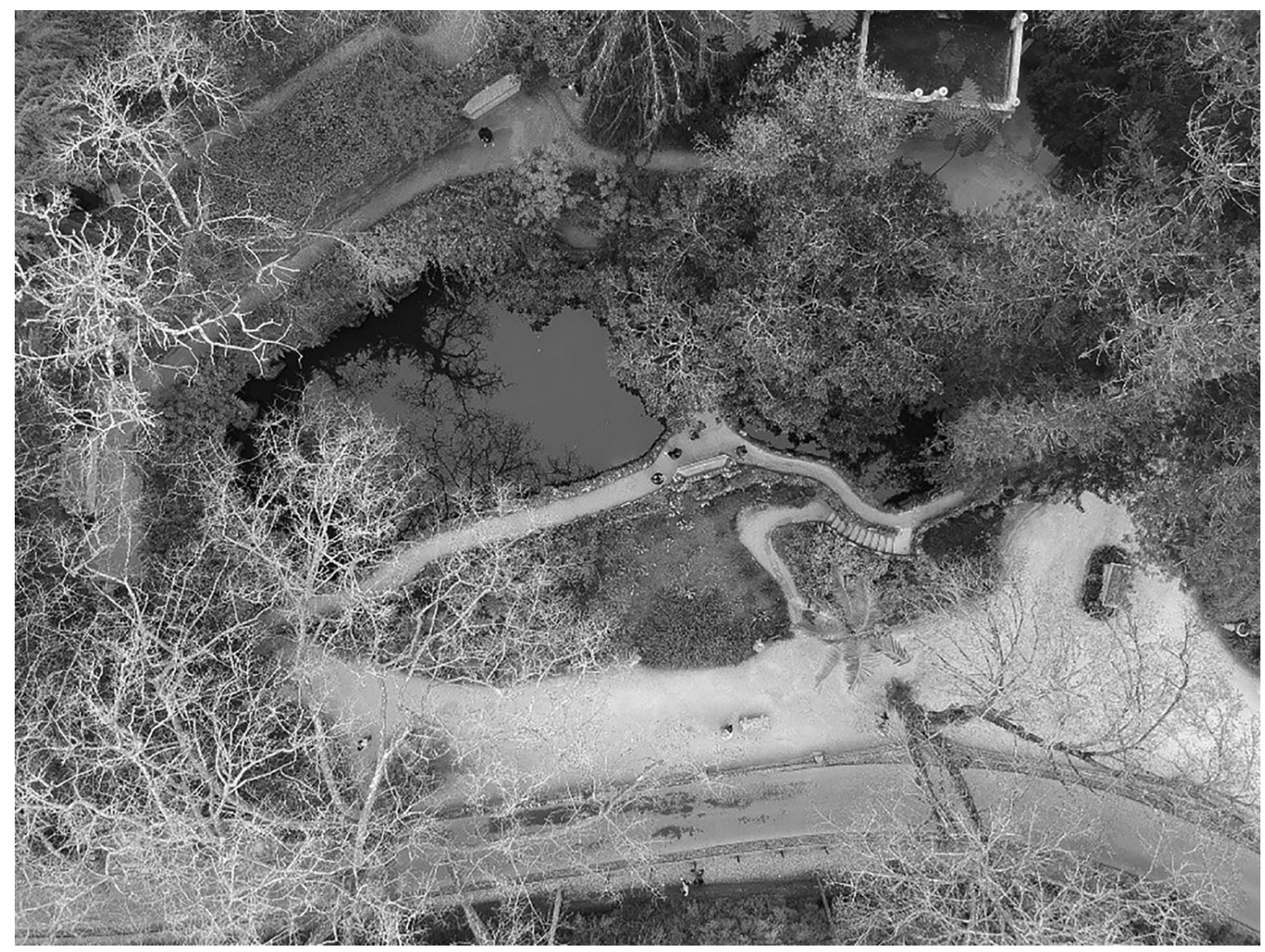

Peculiare caratterizzazione della Quinta da Regaleira è la presenza di alcune misteriose costruzioni di dubbia utilità dalle quali parte un fil rouge che si dirama nell'intero parco tracciando un percorso che suggerisce il passaggio dal mondo intermedio (Purgatorio) al mondo inferiore (Inferno) sino al raggiungimento del mondo superiore (Paradiso), come delineato nella Divina Commedia di Dante. Come scrive Jean-Pierre Bayard, esperto di iniziazioni e simbolismo esoterico, nella sua opera Simbolico dei Mondi Sotterranei, "tutte le tradizioni hanno insegnato che bisogna prima raggiungere il fondo dell'Inferno per iniziare l'ascesa ai mondi celesti; si può raggiungere il Paradiso solo passando per l'Inferno, dando così la prova che si è degni di accedere a un mondo superiore". Per tale motivo, la tenuta 
pare rappresentare nella sua generalità un percorso iniziatico, individuabile soprattutto nei due pozzi che l'hanno resa meta famosa in tutto il mondo. Questi ultimi, denominati il Pozzo Iniziatico e il Pozzo Incompiuto, sono conosciuti come "Ruota Iniziatica" o "Torri invertite". Tale denominazione è relativa alla mancata funzione di raccolta delle acque e legata a riti iniziatici, di probabile matrice massonica, nelle quali la scala in pietra non sale verso il cielo ma si immerge nelle profondità della terra.

II Pozzo Iniziatico presenta una struttura a spirale sviluppata su nove piani, volontario riferimento ai 9 gironi infernali, alle 9 sezioni del Purgatorio e ai 9 cieli del Paradiso, ognuno dei quali è scandito da arcate sostenute da colonne marmoree di raffinata fattura. L'impianto scende a una profondità di 30 metri simboleggianti i canti dell'Inferno dantesco (escludendo i primi due canti introduttivi e quello riguardante gli ignavi). Sul fondo, incisa in intarsi di marmo, spicca una croce templare, insieme a una stella a otto punte, emblema araldico di Carvalho Monteiro e simbolo dei Rosacroce, leggendario ordine segreto ermetico cristiano. II Pozzo Iniziatico è collegato alla seconda torre invertita, denominata Pozzo Incompiuto in quanto mai portato a compimento, da autentici labirinti che attraversano il mondo sotterraneo e conducono inoltre a invasi d'acqua, cascate e attraversamenti in pietra dal grande fascino. Tali strutture ipogee sono state progettate e realizzate dal Manini artificialmente ma sfruttano sapientemente le caratteristiche geologiche del luogo granitico della Serra de Sintra. La Quinta da Regaleira appare, dunque, un crocevia di simboli riconducibili a credi e teorie di pensiero alquanto eterogenei.

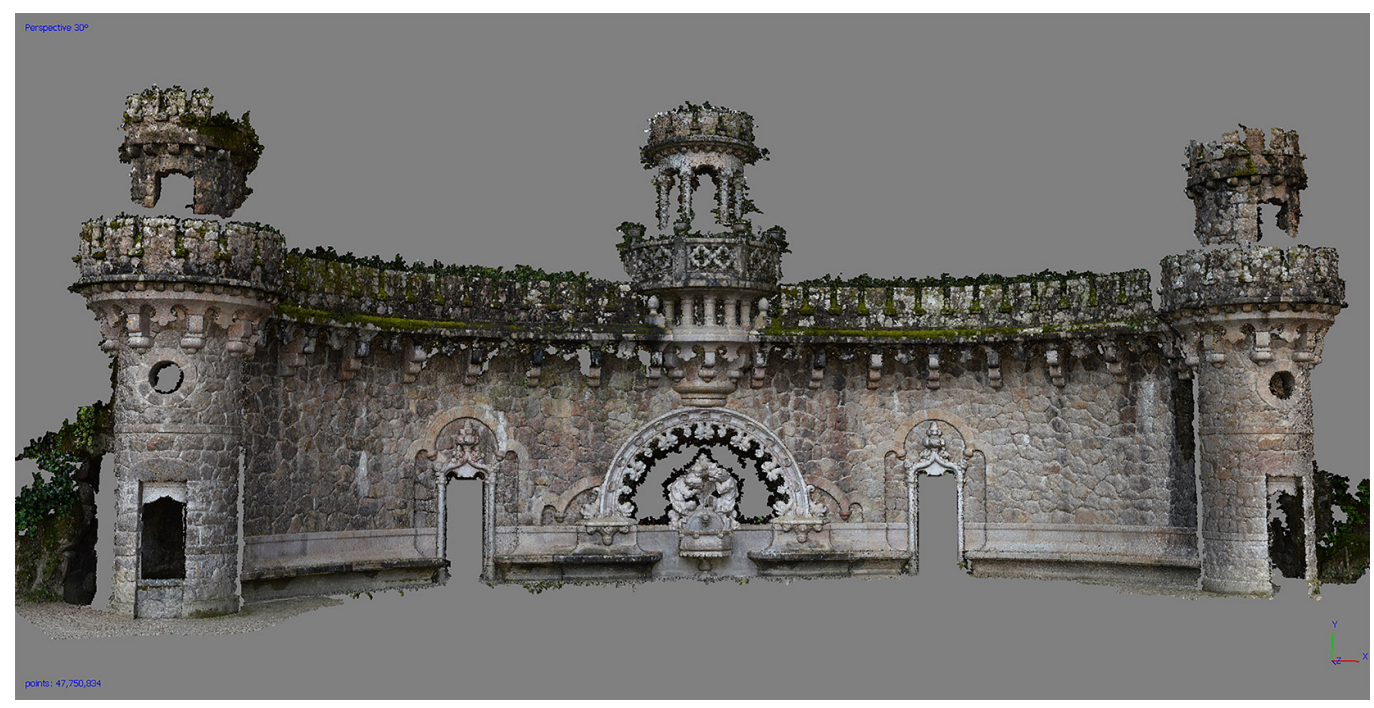

\section{II rilievo e la modellazione digitale}

Nelle attività di rilievo e rappresentazione grafica della Quinta da Regaleira si è scelto di usare la tecnica della fotogrammetria, che consente di ottenere misure accurate da fotografie mediante la trasformazione di informazioni bidimensionali in tridimensionali.Tale metodo di rilievo, inteso come mezzo per giungere a delle informazioni metriche che costituiscono il primo passo verso la conoscenza e la documentazione dell'architettura, negli ultimi anni ha avuto una rapida diffusione in ambito disciplinare.

Com'è noto, il basso costo e la semplicità degli apparecchi usati per svolgere le operazioni fotogrammetriche rappresentano alcuni aspetti che hanno incentivato la diffusione di tale metodo di rilievo. La fotogrammetria rappresenta uno strumento di acquisizione di dati metrici tra i più affidabili e immediati ma, essendo un metodo di rilievo indiretto, non deve e non può sostituirsi completamente ai rilievi diretti. La metodologia fotogrammetrica si fonda 
sul riconoscimento di punti cosiddetti 'omologhi' nei fotogrammi consentendone l'allineamento e la successiva elaborazione in una "nuvola di punti": un modello in cui a ogni punto vengono associate informazioni di posizione $(X, Y, Z)$ e colore (RGB). Un solo fotogramma non contiene informazioni sufficienti a definire univocamente la posizione tridimensionale di ogni punto dell'oggetto. Più fotogrammi generati da punti di presa distinti contengono invece le informazioni necessarie alla ricostruzione univoca della posizione dei punti dell'oggetto nello spazio grazie all'intersezione dei rispettivi raggi omologhi.

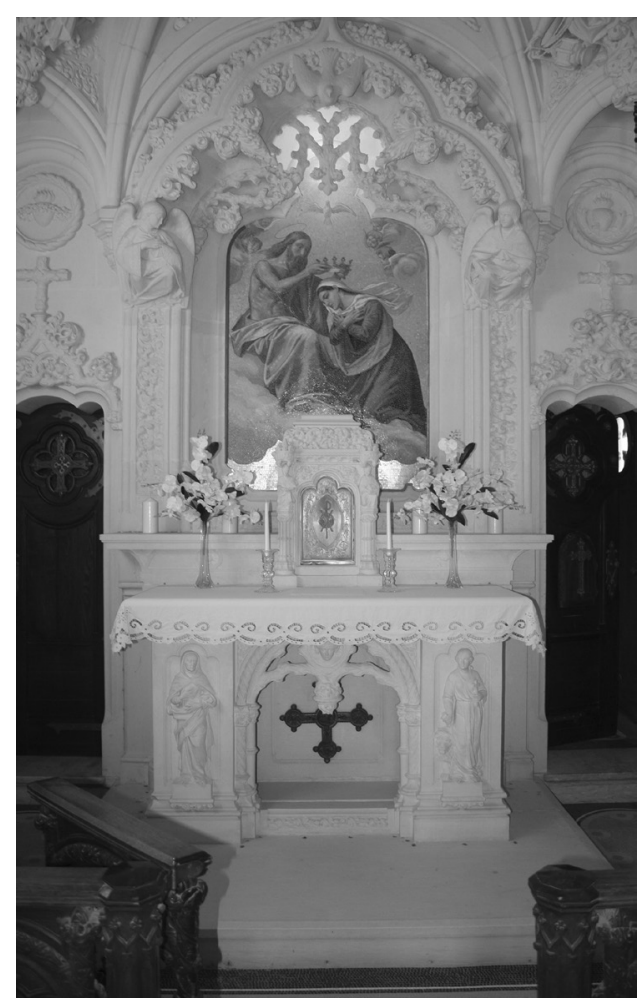

Nel caso studio della Quinta da Regaleira, per un corretto e completo riconoscimento dei punti omologhi da parte del software, le immagini sono state scattate con una sovrapposizione del 80-90\% tramite fotocamera digitale, per gli ambienti interni, e con l'ausilio di drone per gli spazi esterni. Durante la campagna di acquisizione fotografica sono stati eseguiti scatti non solo ortogonali all'oggetto, come era fondamentale nella fotogrammetria tradizionale, ma anche con differenti angolazioni in modo da irrobustire il calcolo e l'elaborazione del modello evitando quindi deformazioni locali da parte del software. Dopo aver importato gli scatti all'interno del software, il workflow operativo ha seguito step specifici. Il primo, definito Image matching, ha consentito di ricostruire la posizione di scatto delle singole immagini e per ogni punto chiave ha ricavato le coordinate spaziali reali materializzate tridimensionalmente in una sparse points cloud, ovvero una nuvola di punti a bassa densità. Durante lo step successivo, denominato structure-from-motion, è stata generata dal software la dense point cloud caratterizzata da un numero molto elevato di punti capaci di restituire una percezione molto realistica dell'oggetto di studio rilevato. Infine, durante l'ultima fase il software, a partire da dati non strutturati, come la nuvola di punti, ha generato dati strutturati che prendono il nome di mesh. Ė stata quindi realizzata una superficie continua composta da un insieme di poligoni triangolari, i cui vertici corrispondono ai punti della nuvola di punti, che costituisce il modello 3D vero e proprio dal quale sono stati ricavate rappresentazioni bidimensionali quali piante prospetti e sezioni. 
La modellazione tridimensionale risulta essere uno strumento fondamentale per l'attività di rilievo nella Quinta da Regaleira, attraverso il quale è possibile indagare i sistemi interni compositivi e i flussi funzionali che mettono in relazione tra loro le architetture epigee e ipogee del Parco. Questo processo ha permesso di ottenere uno studio dell'intera tenuta e di comprendere le relazioni che intercorrono tra i manufatti, i dislivelli e i volumi architettonici. Tali connessioni si percepiscono mediante la realizzazione di spaccati territoriali tridimensionali nei quali la scelta della linea di sezione tende a operare un taglio che interseca gli elementi paesaggistici, le architetture e la componente ipogea, esponendo all'occhio umano la bellezza compositiva, grafica e strutturale dell'opera.

I modelli 3D sono stati inoltre alla base della realizzazione di filmati interattivi multirisoluzione, sviluppati attraverso l'uso di software innovativi, compatibili con diversi supporti digitali, quali visori 3D, smartphone e tablet. Tali prodotti digitali determinano nel visitatore una maggiore comprensione delle forme geometriche dell'architettura e del paesaggio, agevolando i flussi di transito tra le strutture, gli ambienti del sottosuolo e gli spazi verdi che le circondano.

II risultato ottenuto tramite l'interazione di tecniche di rilevo tradizionali a quelle innovative e digitali è un racconto bidimensionale e tridimensionale della Quinta da Regaleira costituendo un inedito percorso di conoscenza grafica e teorica del territorio portoghese.
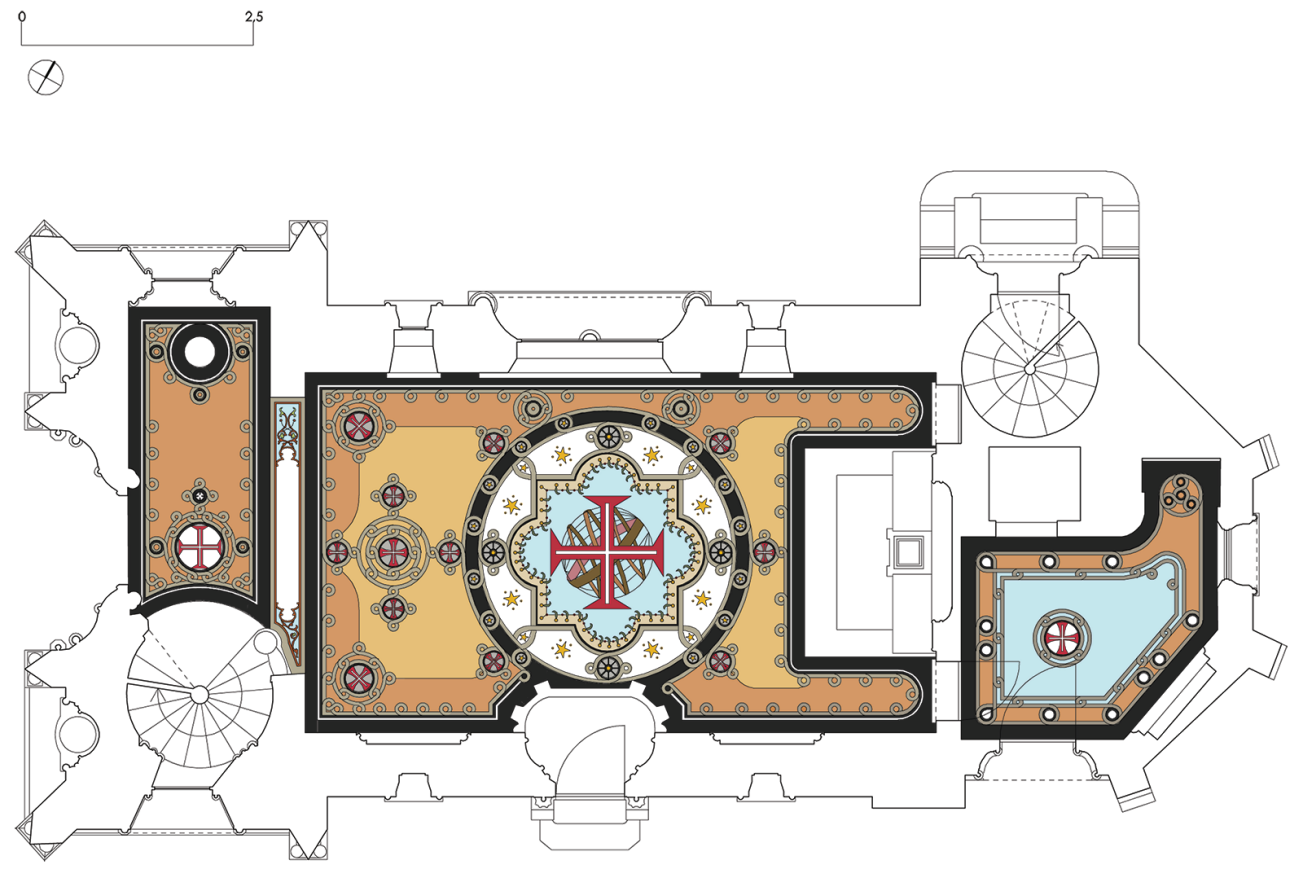

\section{Conclusioni}

II contributo delinea le caratteristiche architettoniche, strutturali e simboliche della Quinta da Regaleira, importante esempio di coesione tra architettura e paesaggio. II Manini sembra infatti aver concepito il Parco portoghese come un'immensa scena lirica. Appare, quindi, evidente la teatralizzazione dello spazio, intesa come mezzo visivo per suscitare la sorpresa e l'irreale, per suggerire esperienze e sentimenti che attraggono l'intrigo e il pittoresco. 
Fig. 6. La Quinta da

Regaleira a Sintra, o

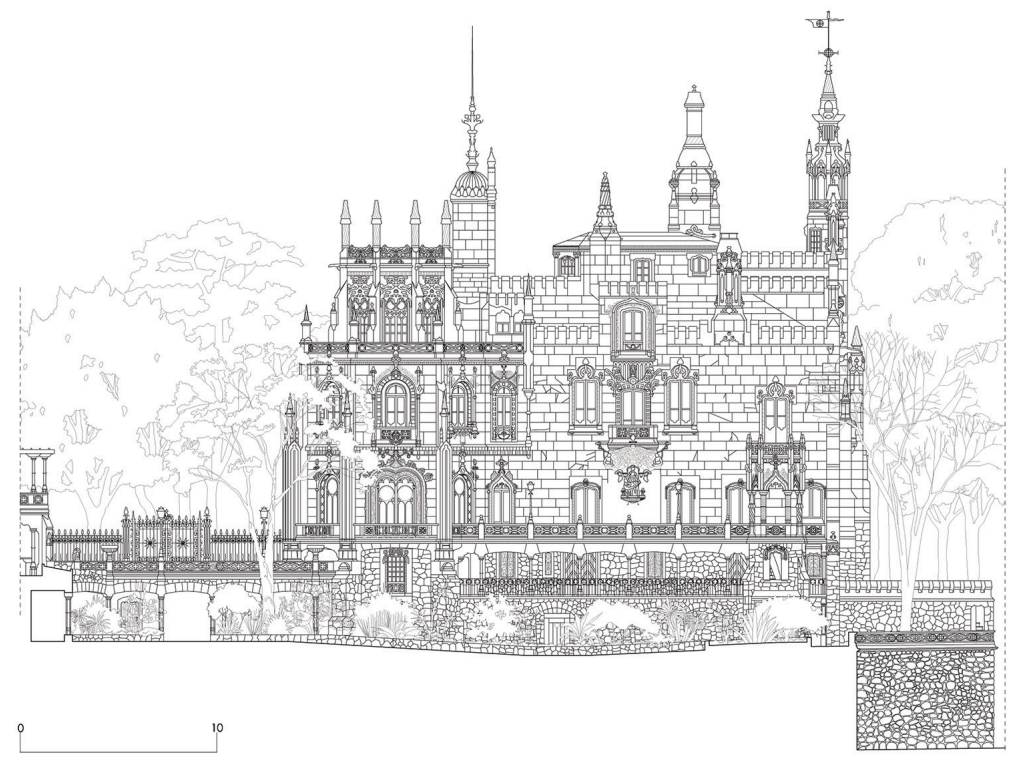

Fig. 7. La Quinta da

Regaleira a Sintra, a Torre

da Regaleira e a Gruta da

Leda, sezione trasversale.

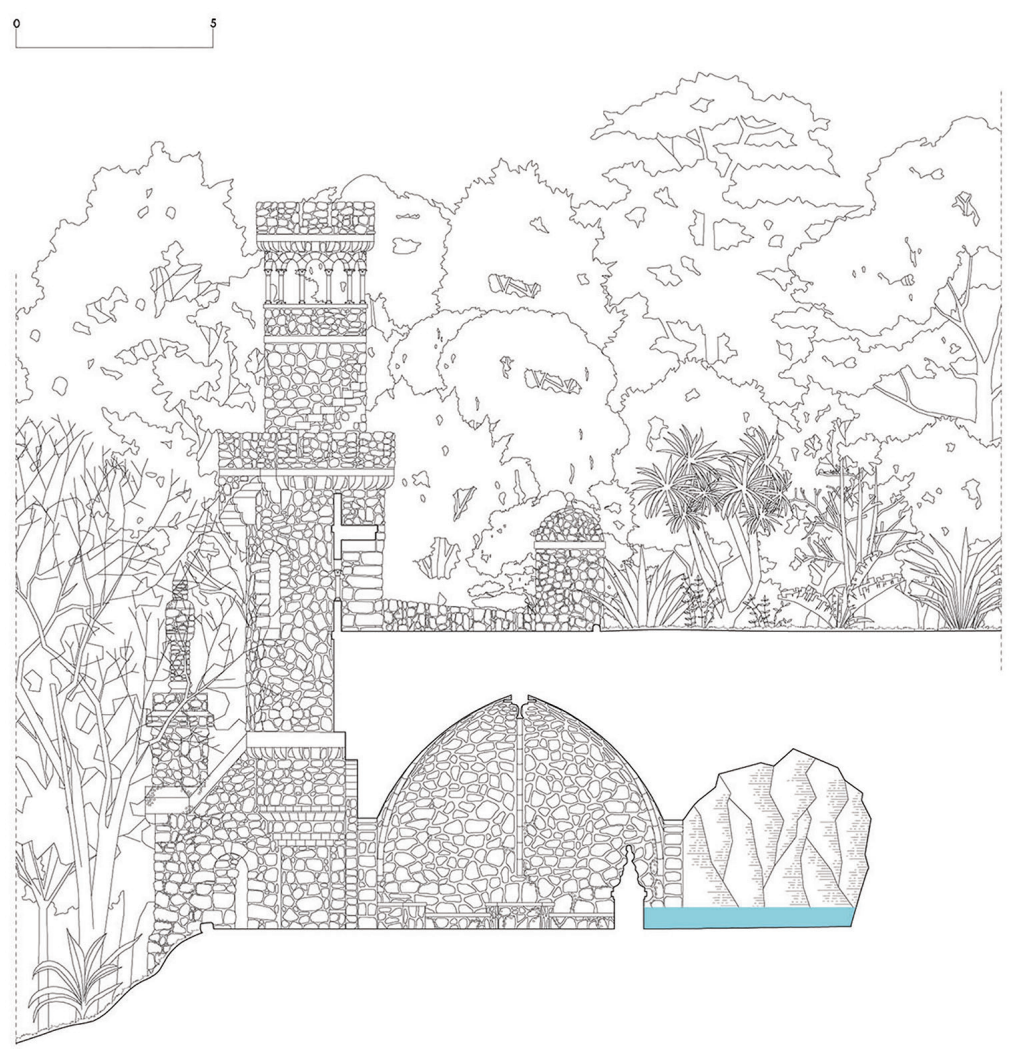



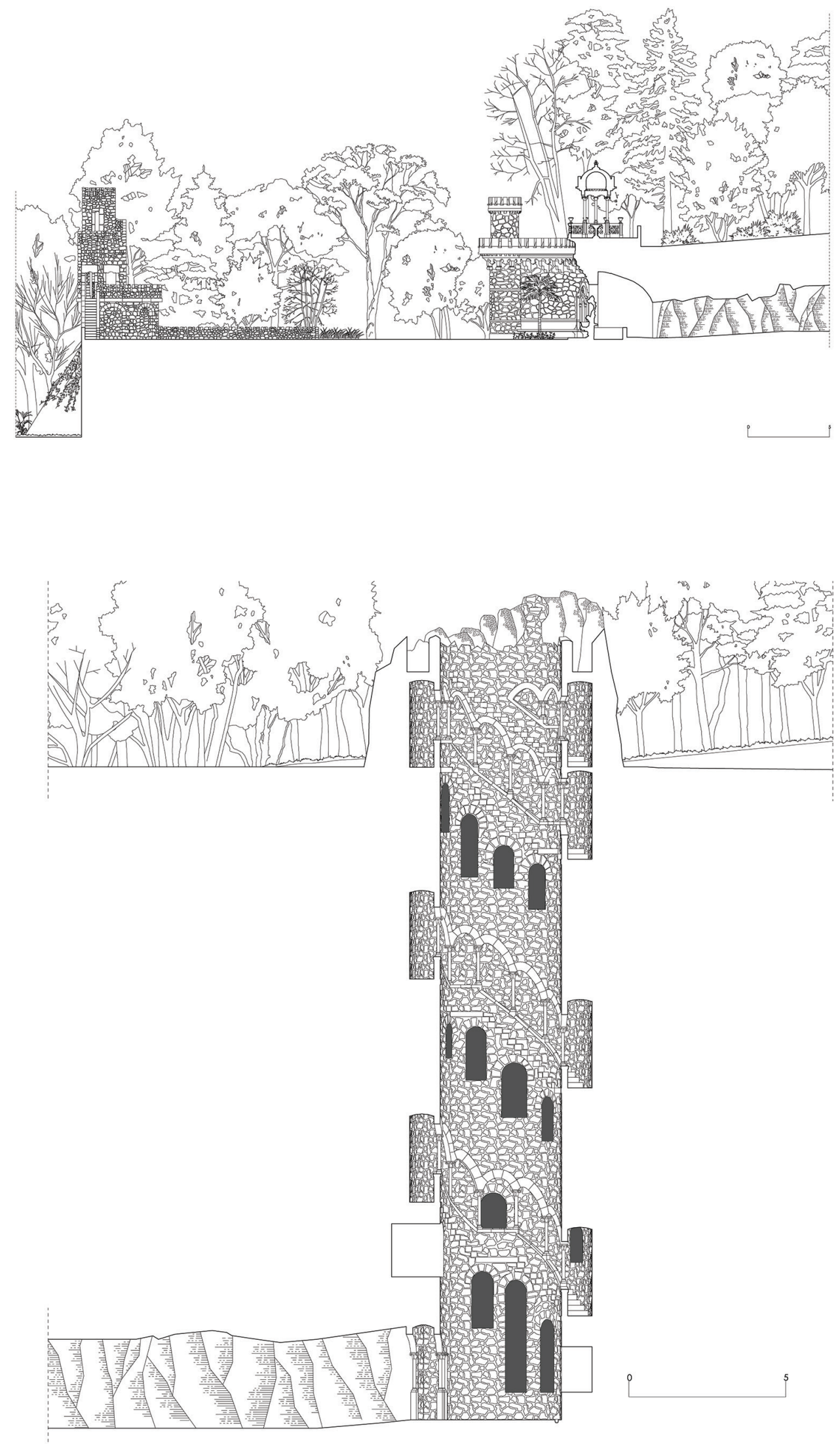
Fig. 10. La Quinta da Regaleira a Sintra digitalizzazione grafica del modello tridimensionale sezionato in assonometria del Lago da Cascata.

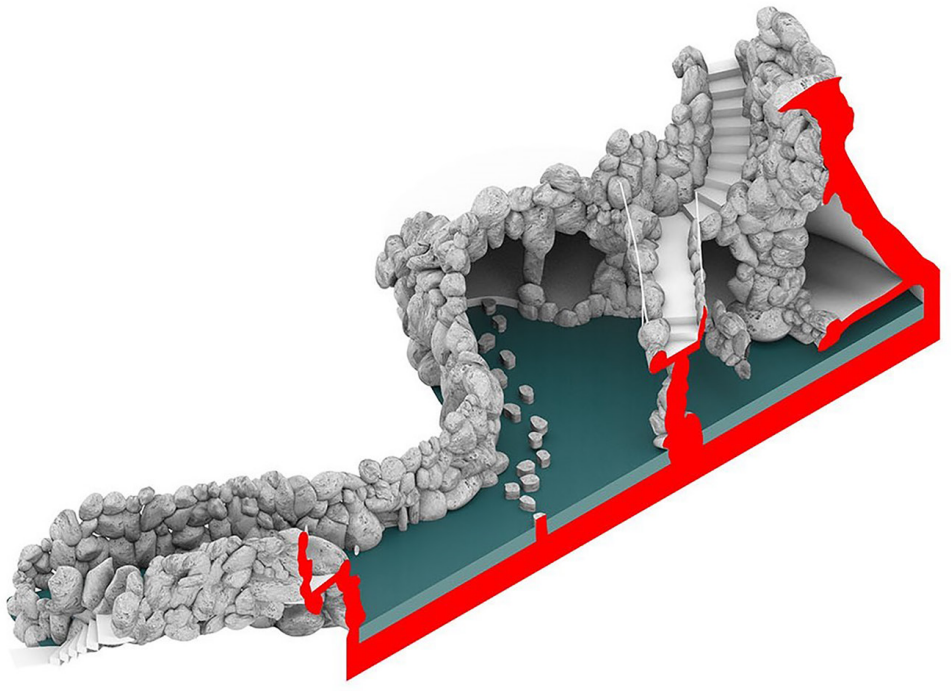

L'eclettismo degli stili utilizzati e l'inaspettata trasformazione del paesaggio permettono di stimolare nella mente di chi percorre i sinuosi viali del Parco una suspense scenografica, incentrata sul carattere imprevedibile delle prospettive, sull'enigmatico rapporto tra costruito e naturale, tra il filo dell'orizzonte inghiottito dall'esuberanza del paesaggio e gli assi verticali che fanno appello al cielo e alle profondità della terra. L'uso di software interattivi per la restituzione grafica, la rappresentazione digitale, l'impiego della tecnica fotogrammetrica e la modellazione 3D ha permesso la conoscenza e la successiva documentazione dell'aspetto attuale della tenuta, ponendo le basi non solo per un procedimento scientifico, utilizzabile su altri manufatti architettonici, ma soprattutto per la tutela e promozione del sito UNESCO.
Fig. I I. La Quinta da Regaleira a Sintra, modello tridimensionale vista zenitale del Poço Iniciático.

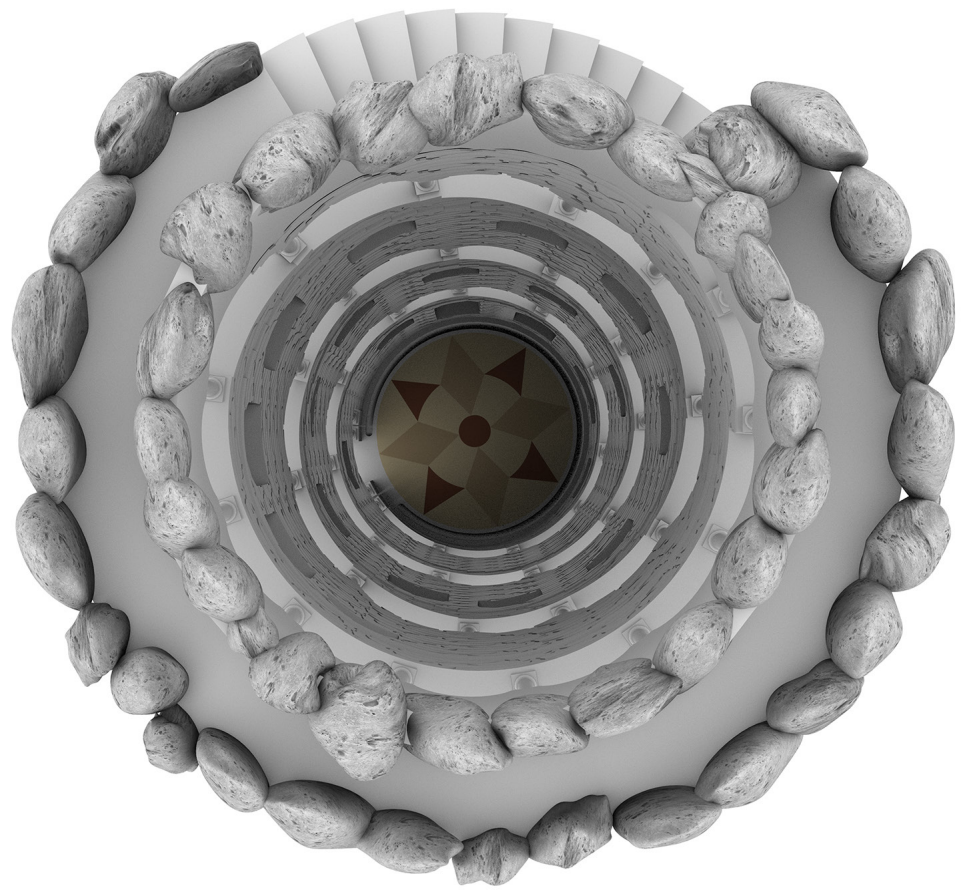




\section{Riferimenti bibliografici}

Amoruso G. et al. (20 I I). Realtà, simulazione e progetto. Il ruolo del modello. Santarcangelo di Romagna: Maggioli Editore.

Apollonio F. I. (20I2). Architettura in 3D. Modelli digitali per i sistemi cognitivi. Milano: Bruno Mondadori.

Bertocci S., Parrinello S. (20I5). Digital Survey and Documentation of the Archeological and Architectural sites. UNESCO World Heritage list. Firenze: Edifir edizioni.

Carlevaris L., Filippa M. (a cura di) (20I2). Elogio della teoria. Identità delle discipline del disegno e del rilievo. Atti del IX Congresso dell'Unione Italiana per il Disegno. Roma, I3- 15 dicembre 2012. Roma: Gangemi Editore.

Corniello L. (2019). Il disegno del Parco Reale di Tirana. Napoli: La scuola di Pitagora editrice.

Docci M., Gaiani M., Maestri D. (20I I). La scienza del Disegno. Milano: CittàStudi.

França J. A. (2004). História da arte em Portugal. O Pombalismo e o Romantismo. Lisbona: Editorial Presença.

Fundação Cultursintra (2006). Quinta da Regaleira, Luigi Manini: imaginário \& método, arquitectura \& cenografia, exposição internacional. Sintra: Fundação Cultursintra.

Gaiani M. (20|4). Smart City: dal rilievo ex-post al rilievo ex-ante. In M. Unali. Atlante dell'abitare virtuale. II Disegno della Città Virtuale, fra Ricerca e Didattica, pp. I 17- I23. Roma: Gangemi editore.

Giandebiaggi P., Zerbi A. (20 I5). Rilievo metrico e fotogrammetrico. In R. Cadignani. La torre Ghirlandina. Cronaca del restauro e studi recenti, pp. 18-20. Roma: Luca Sossella edizioni.

Giordano P. (20 I6). II disegno dei parchi urbani. In G. M. Cennamo. Processi di analisi per strategie di valorizzazione dei paesaggi urbani, pp. 79-88. Roma: Ermes Editore.

Janeiro P. A. (20।8). O desenho do céu da rua, Tres Metodologias para a Representacao Figurativa da Rua e dos seus Objectos. Lisbona: Chiado Editora.

Luigini A. (2007). Simulare la visione della realtà. Strumenti digitali per la visualizzazione avanzata, Simulating the Vision of Reality. In P.Tunzi. Virtualità del Reale. Dalla misura lineare alla visualizzazione 3D di antiche fabbriche. Roma: Edizioni Kappa.

Martins R. (20l3). A Mensagem Alquimica da Quinta da Regaleira: Elementos de Alquimia e Esoterismo na Gramática Decoratica da Regaleira. CreateSpace Independent Publishing Platform.

Piccarolo G., Ricci G. (2007). Luigi Manini (1 848-1936). Architetto e scenografo, pittore e fotografo, catalogo della mostra (Crema, 6 maggio-8 luglio 2007). Cinisello Balsamo: Silvana editoriale.

Piga B. E. A., Salerno R. (20 17). Urban Design and Representation. A Multidisciplinary and Multisensory Approach. Cham: Springer International Publishing.

Vitali M. (2010). La rappresentazione tridimensionale in ambito urbano. In C. Boido, D. Coppo. Rilievo urbano. Conoscenza e rappresentazione della città consolidata, pp. | 32- |37. Firenze: Alinea.

\section{Autori}

Gennaro Pio Lento, Università degli Studi della Campania “Luigi Vanvitelli”, gennaropio.lento@unicampania.it Fabiana Guerriero, Università degli Studi della Campania "Luigi Vanvitelli", fabiana.guerriero@unicampania.it

Luigi Corniello, Università degli Studi della Campania “Luigi Vanvitelli”, luigi.corniello@unicampania.it

Pedro António Janeiro, Universidade de Lisboa, pajaneiro@gmail.com

Per citare questo capitolo: Lento Pio Gennaro, Guerriero Fabiana, Corniello Luigi, Janeiro Pedro António (2021). Linguaggi architettonici ed esoterici per la rappresentazione della Quinta da Regaleira a Sintra/Architectural and esoteric languages for the representation of the Quinta da Regaleira in Sintra. In Arena A., Arena M., Mediati D., Raffa P. (a cura di). Connettere. Un disegno per annodare e tessere. Linguaggi Distanze Tecnologie. Atti del $42^{\circ}$ Convegno Internazionale dei Docenti delle Discipline della Rappresentazione/Connecting. Drawing for weaving relationship. Languages Distances Technologies. Proceedings of the $42^{\text {th }}$ International Conference of Representation Disciplines Teachers. Milano: FrancoAngeli, pp. 859-878. 


\title{
Architectural and Esoteric Languages for the Representation of the Quinta da Regaleira in Sintra
}

\author{
Gennaro Pio Lento \\ Fabiana Guerriero \\ Luigi Corniello \\ Pedro António Janeiro
}

Abstract

The research focuses on an unprecedented analysis of the Quinta da Regaleira, located in the heart of the UNESCO site of Sintra, focusing on the peculiarities of the dual architectural component: epigeal, symbolising paradise, which develops following the contours of the hill, and hypogeal, with underground routes that recall Dante's inferno. These scenarios materialise an initiatory journey, a peregrinatio vera mundi, through a symbolic garden rich in references to mythology, Virgilian epics, the Templar mission of the Order of Christ and alchemy.

The study was characterised by a preliminary analysis of the existing bibliography, mainly oriented to the historical and symbolic narration of the Park, and of the graphic sources of the Italian architect Luigi Manini. The survey activity was carried out using consolidated methodologies of the discipline, implemented through instrumental activities and through modelling and interactive digital visualisation using films developed with innovative software. In addition to an innovative interactive, digital, graphic and iconographic database, the works produced constitute a symbolic reference of the architecture within the Quinta da Regaleira, which has made it famous and attracts millions of visitors every year.

Keywords

survey, drone, modelling, Sintra, UNESCO.

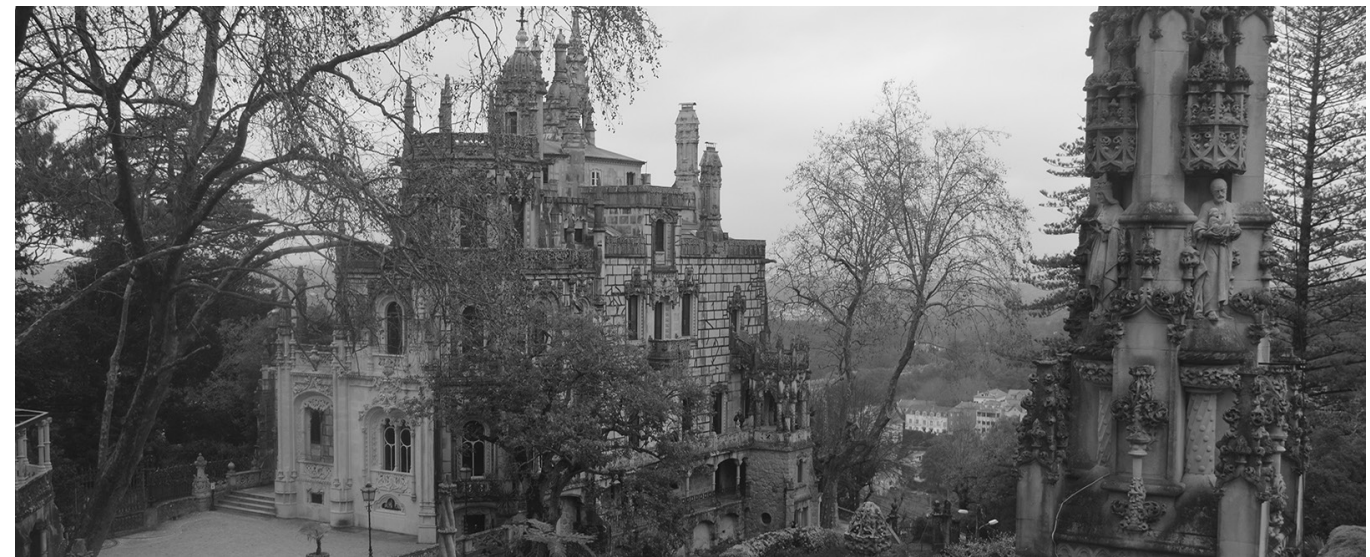




\section{Introduction}

The Quinta da Regaleira, an enigmatic architectural and vegetation complex of great value and charm, is part of the beauty that characterises the Portuguese territory. The hill town of Sintra, where the estate is located, was recognised as a World Heritage Site in 1995 at the 19th session of the UNESCO World Heritage Committee held in Berlin, triggering the definition of the "Cultural Landscape" category by UNESCO.

The unprecedented study of the epigean and hypogean architectural system, as well as the large garden, carried out by means of manual and instrumental survey, intended as a scientific research tool for the knowledge and conservation of the heritage, The study of the epigean and hypogean architectural system and of the large garden, carried out by manual and instrumental survey, as a scientific research tool for knowledge and conservation of the heritage, has outlined its interesting architectural and structural characteristics, focusing on the symbolic language adopted by the creative genius of the Italian architect and stage designer Luigi Manini and the possible esoteric interpretation that can be attributed to it. It also offers the possibility of consulting new sources for possible future interventions aimed at preserving the rich patrimonial value of the Unesco site, but also at enhancing and using it for the benefit of posterity.

Fig. I.The Quinta da Regaleira in Sintra general plan.

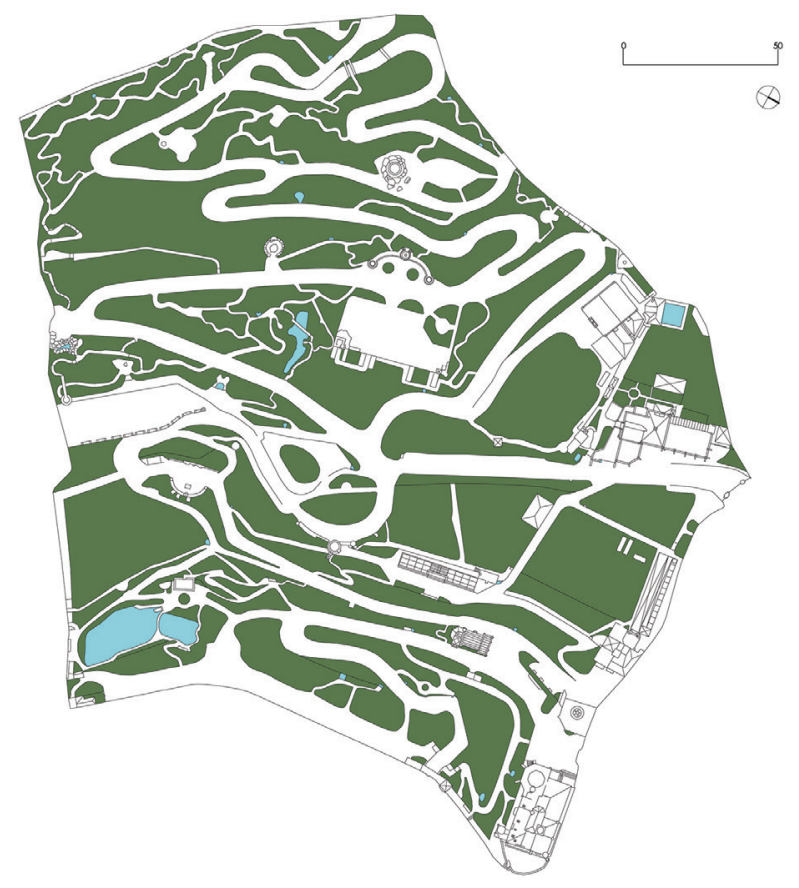

Symbols and structures in the Quinta da Regaleira

A few kilometres from Lisbon, in the heart of the city of Sintra, stands the Quinta da Regaleira, a striking example of the interpenetration of architecture and vegetation in the tradition of the great European gardens, covering four hectares of land on the slopes of the Serra mountain range. The park, which has belonged to various owners over the centuries, including the Baroness of Regaleira, from whom it takes its name, owes its current appearance to the wealthy and eccentric Brazilian-Portuguese entomologist, coffee merchant and Freemason Antonio Augusto de Carvalho Monteiro, who acquired the estate at the end of the 19th century. Dissatisfied with the medieval-style project delivered by the French architect Henri Lusseau, the wealthy owner commissioned the Italian architect and stage designer Luigi Manini to carry out the entire renovation of the estate in 1898 , in order to realise his 
dream of a residence that would be able to adequately display not only the enormous wealth he had accumulated in Brazil, but also his personal and complex cultural universe. Manini, accustomed to adapting his skills to the demands of his clients, enthusiastically accepted the challenge and saw it as an opportunity to escape the sterile repetition of architectural models of the time. The opportunity was to put his romantic soul as a painter and creator of fantastic landscapes to the test, revisiting Neo-Manueline in a new key. The Italian architect initially took charge of the design of the imposing residence, positioning it at the foot of the verdant estate. However, the first project for the Regaleira Palace was abandoned in favour of a less ambitious design, in which the distribution spaces, considerably reduced in size, are concentrated along the central axis of the rectangle that forms the layout of the building. The exterior elevations, adorned with buttresses, pinnacles and porticoes, are characterised by the fusion of different styles, including Neo-Mauneline, Gothic and Renaissance, with important esoteric and alchemical references.

In the garden characterised by infinite shades of green that surrounds the palace and to which the architecture aspires to blend in, there are a number of structures designed to house different functions, in accordance with the styles used but smaller in size, such as a chapel, a greenhouse, a generator's house and stables.

Fig. 2.The Quinta da Regaleira in Sintra, a Gruta do Labirinto, drone survey.

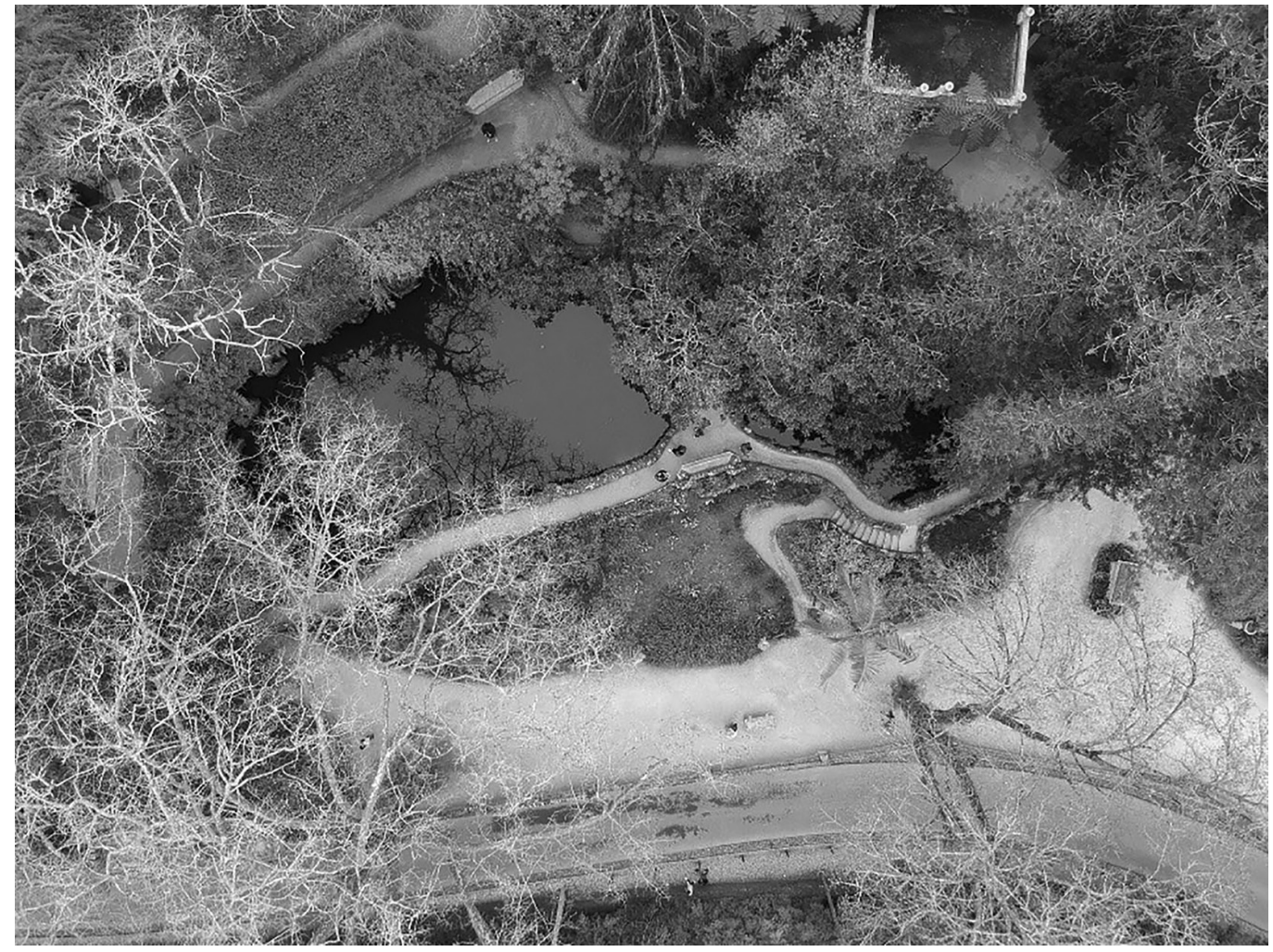

A special feature of the Quinta da Regaleira is the presence of a number of mysterious constructions of dubious usefulness, from which a thread runs through the entire park, tracing a route that suggests the passage from the intermediate world (Purgatory) to the lower world (Hell) and on to the upper world (Paradise), as outlined in Dante's Divine Comedy. As Jean-Pierre Bayard, an expert in initiations and esoteric symbolism, writes in his work Symbolic of the Underworlds, "all traditions have taught that one must first reach the bottom of Hell to begin the ascent to the celestial worlds; one can only reach Paradise by passing through Hell, thus proving that one is worthy of entering a higher world". For this reason, the estate seems to represent in its generality an initiatory path, identifiable above all in the 
two wells that have made it a world-famous destination. The latter, called the Initiatory Well and the Unfinished Well, are known as the "Initiatory Wheel" or "Inverted Towers". This name relates to the lack of water collection functions and is linked to initiation rites, probably of Masonic origin, in which the stone staircase does not climb to the sky but plunges into the depths of the earth.

The Initiatory Well has a spiral structure developed on nine floors, a deliberate reference to the 9 circles of Hell, the 9 sections of Purgatory and the 9 heavens of Paradise, each of which is marked by arches supported by finely crafted marble columns. The structure descends to a depth of 30 metres, symbolising the cantos of Dante's Inferno (excluding the first two introductory cantos and the one concerning the unsuspecting). At the bottom, engraved in marble inlays, is a Templar cross, together with an eight-pointed star, the heraldic emblem of Carvalho Monteiro and symbol of the Rosicrucians, a legendary secret hermetic Christian order.The Initiatic Well is connected to the second inverted tower, known as the Unfinished Well because it was never completed, by authentic labyrinths that traverse the underground world and also lead to water reservoirs, waterfalls and fascinating stone crossings. These underground structures were designed and built by Manini artificially but skilfully exploit the geological characteristics of the granite site of the Serra de Sintra. The Quinta da Regaleira thus appears to be a crossroads of symbols from a wide variety of beliefs and theories.

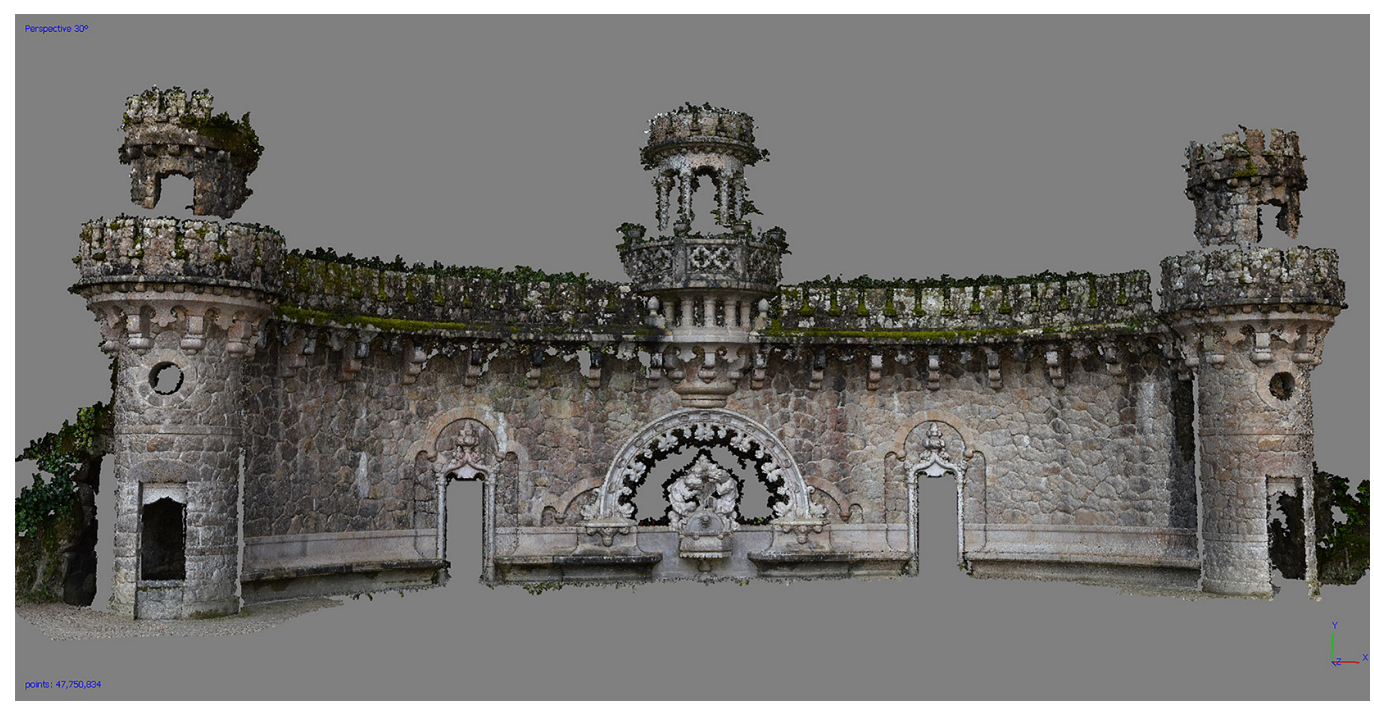

\section{The survey and digital modelling}

In the survey and graphic representation of the Quinta da Regaleira, it was decided to use the technique of photogrammetry, which makes it possible to obtain accurate measurements from photographs by transforming two-dimensional information into three-dimensional information. This method of survey, intended as a means of obtaining metric information that constitutes the first step towards the knowledge and documentation of architecture, has been rapidly spreading in recent years in the disciplinary field.

As is well known, the low cost and simplicity of the equipment used to carry out photogrammetric operations are some of the aspects that have encouraged the diffusion of this survey method. Photogrammetry is one of the most reliable and immediate tools for acquiring metric data, but as it is an indirect surveying method, it must not and cannot completely replace direct surveys. The photogrammetric method is based on the recognition of so-cal- 
led "homologous" points in the frames, allowing them to be aligned and then processed in a "point cloud": a model in which each point is associated with position $(X, Y, Z)$ and colour (RGB) information. A single frame does not contain enough information to unambiguously define the three-dimensional position of each point on the object. On the other hand, several frames generated by separate gripping points contain the information necessary to univocally reconstruct the position of the object points in space thanks to the intersection of their respective homologous rays.

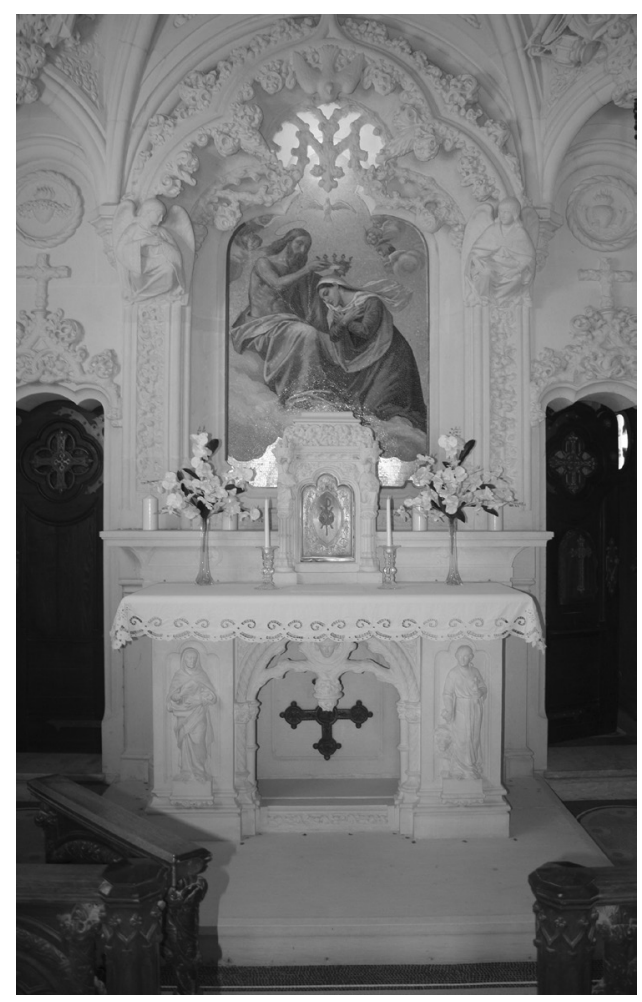

In the case study of the Quinta da Regaleira, for a correct and complete recognition of the homologous points by the software, the images were taken with an $80-90 \%$ overlap using a digital camera, for the interior spaces, and with the aid of a drone for the exterior spaces. During the photographic acquisition campaign, shots were taken not only orthogonal to the object, as was fundamental in traditional photogrammetry, but also at different angles in order to strengthen the calculation and processing of the model, thus avoiding local deformations by the software. After importing the shots into the software, the operational workflow followed specific steps. The first, called Image matching, allowed the reconstruction of the shooting position of the single images and, for each key point, obtained the real spatial coordinates materialised three-dimensionally in a sparse points cloud. During the next step, called structure-from-motion, the software generated the dense point cloud characterised by a very high number of points capable of giving a very realistic perception of the object of study detected. Finally, during the last phase, the software, starting from unstructured data, such as the point cloud, generated structured data that are called meshes. A continuous surface composed of a set of triangular polygons, whose vertices correspond to the points of the point cloud, was then created, which constitutes the actual 3D model from which two-dimensional representations such as plans, elevations and sections were obtained. Three-dimensional modelling has proved to be a fundamental tool for the survey activity in the Quinta da Regaleira, through which it is possible to investigate the internal compositio- 
nal systems and functional flows that relate the epigean and hypogean architectures of the Park. This process has made it possible to obtain a study of the entire estate and to understand the relationships that exist between the artefacts, the gradients and the architectural volumes. These connections are perceived through the creation of three-dimensional territorial cutaways in which the choice of section line tends to make a cut that intersects the landscape elements, the architecture and the underground component, exposing the compositional, graphic and structural beauty of the work to the human eye. The 3D models were also the basis for the creation of multi-resolution interactive films, developed through the use of innovative software, compatible with different digital media, such as 3D viewers, smartphones and tablets. These digital products give the visitor a greater understanding of the geometric shapes of the architecture and landscape, facilitating the flow of transit between the structures, the underground environments and the green spaces surrounding them.

The result obtained through the interaction of traditional surveying techniques with innovative and digital ones is a two and three-dimensional account of the Quinta da Regaleira, constituting an unprecedented path of graphic and theoretical knowledge of the Portuguese territory.

Fig. 5.The Quinta da Regaleira in Sintra, a Capela, chromatic plan of the flooring.
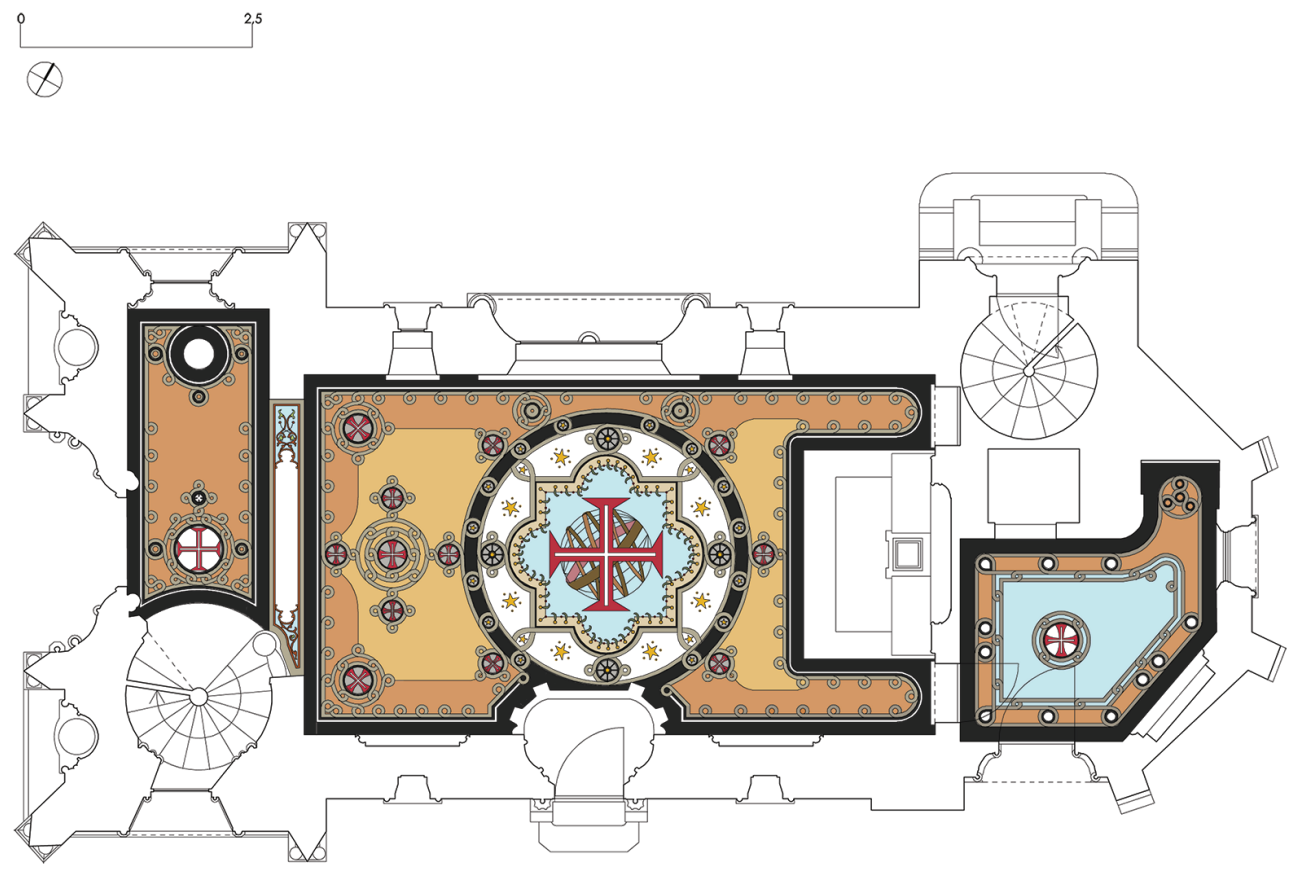

\section{Conclusions}

The contribution outlines the architectural, structural and symbolic characteristics of the Quinta da Regaleira, an important example of cohesion between architecture and landscape. Manini seems to have conceived the Portuguese Park as an immense lyrical scene. The theatricalisation of space is therefore evident, intended as a visual means to arouse surprise 
Fig. 6.The Quinta da

Regaleira in Sintra, o

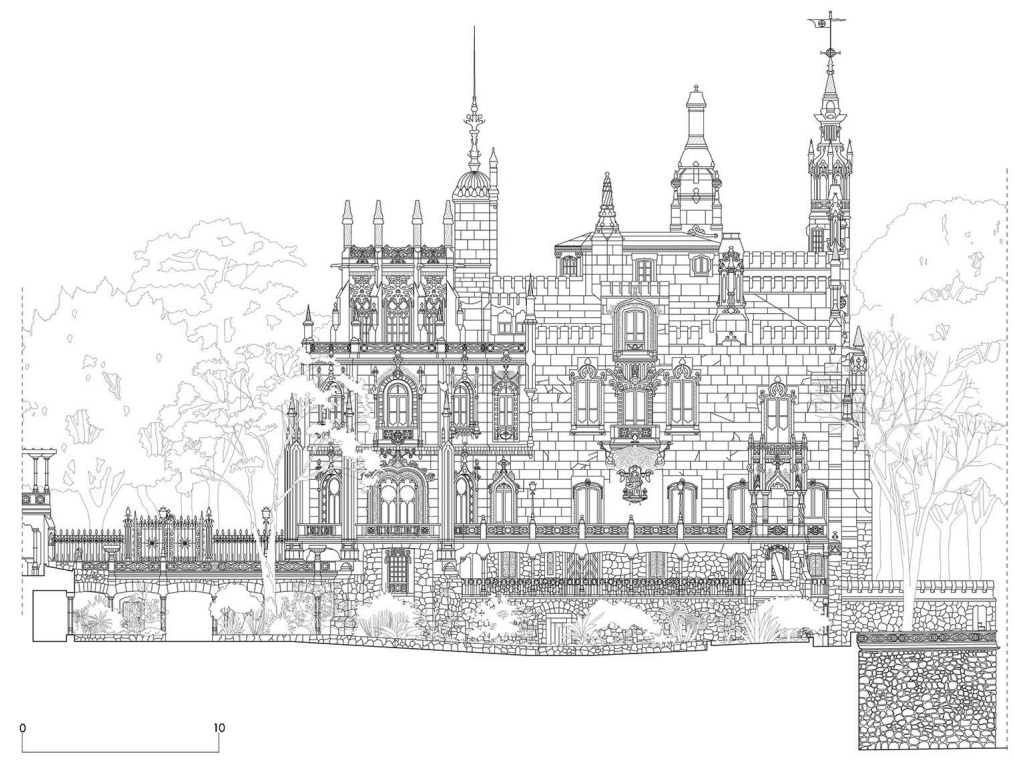

Fig. 7.The Quinta da

Regaleira in Sintra, a Torre

da Regaleira and a Gruta

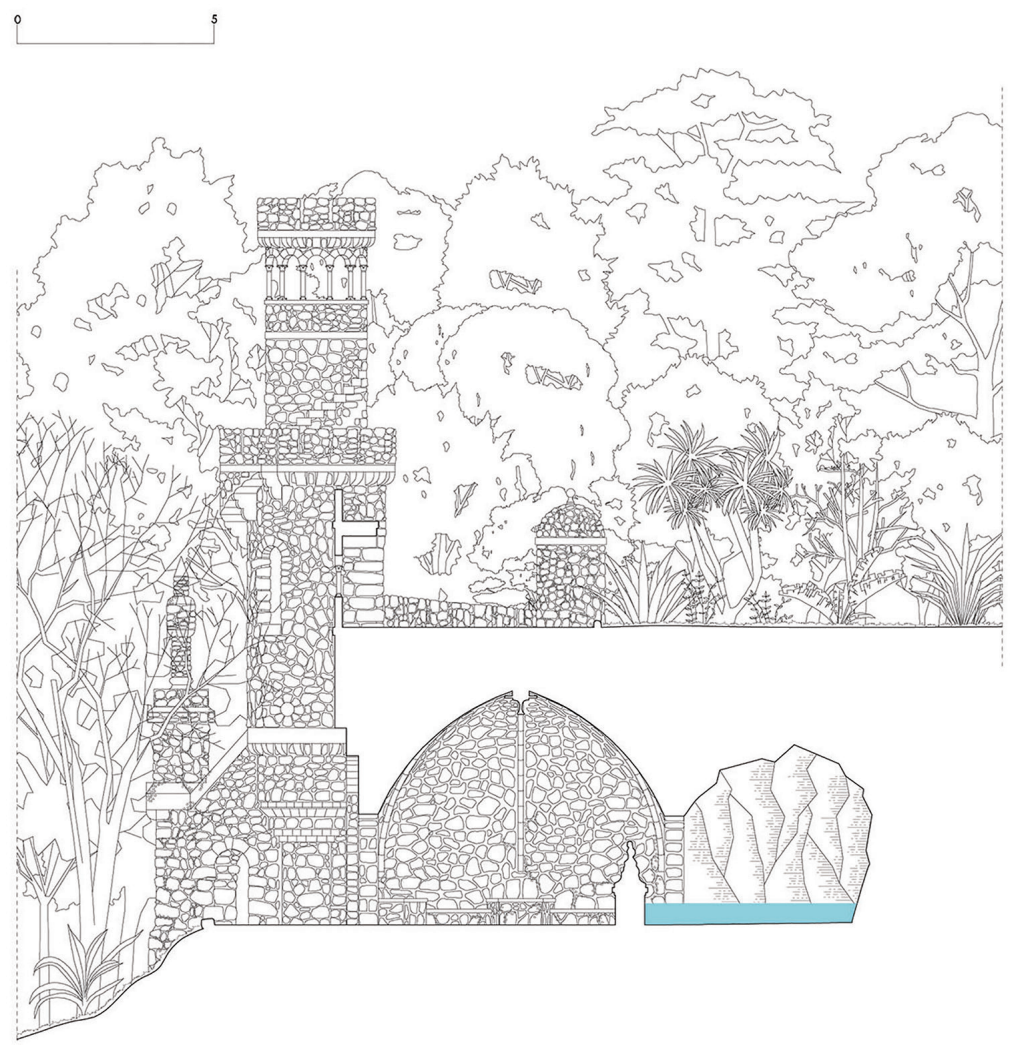



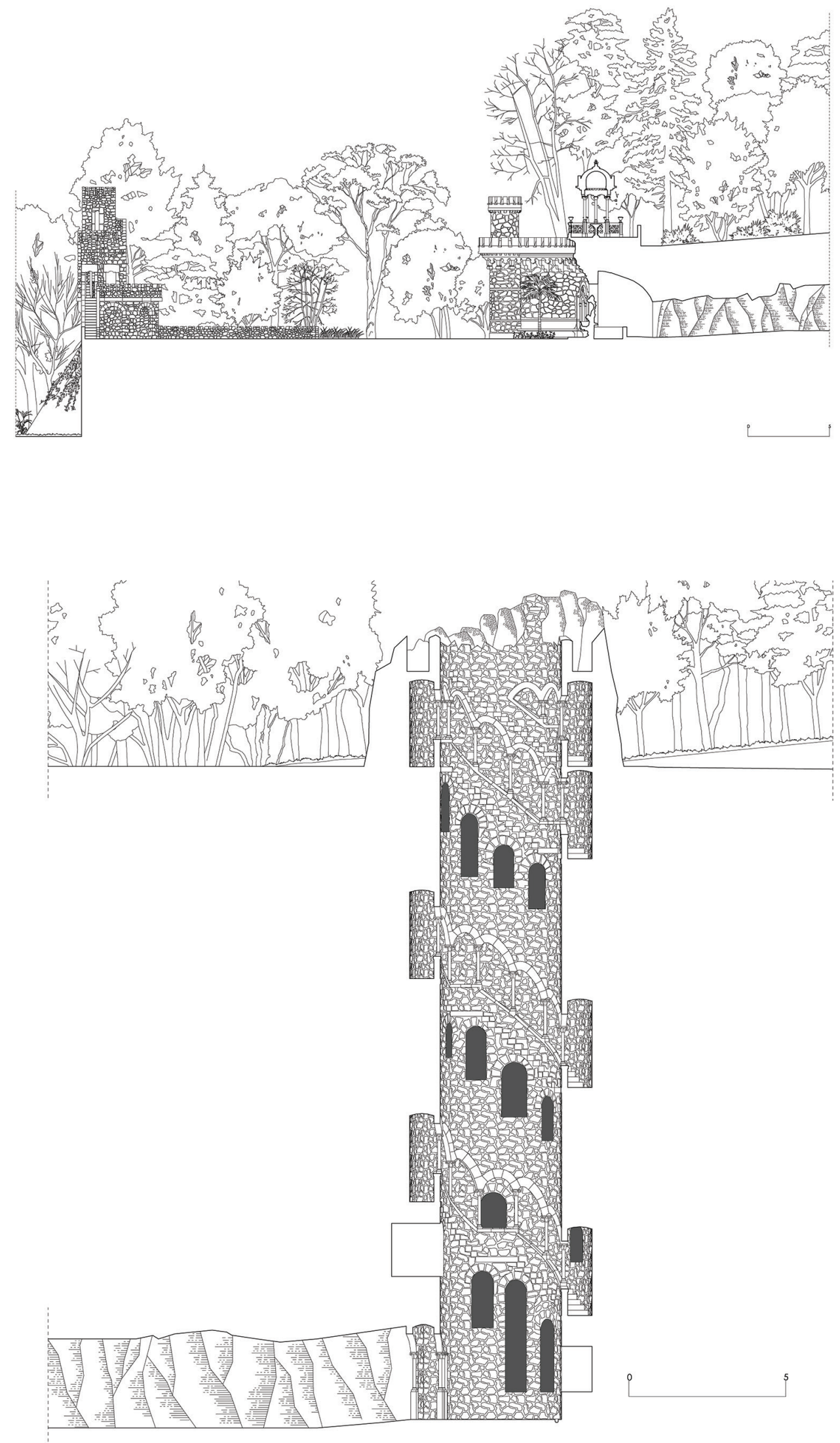
Fig. I The Quinta da Regaleira in Sintra, graphic digitisation of the three-dimensional model sectioned in axonometry of the Lago da Cascata.

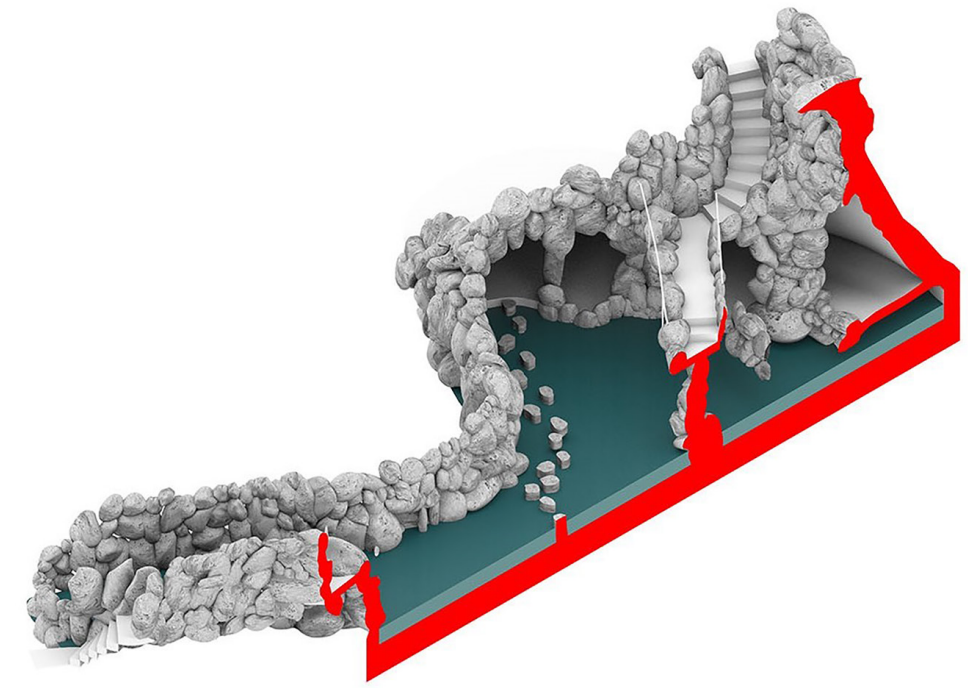

and the unreal, to suggest experiences and feelings that attract intrigue and the picturesque. The eclecticism of the styles used and the unexpected transformation of the landscape allow to stimulate in the mind of those who walk along the winding avenues of the Park a scenographic suspense, centred on the unpredictable character of the perspectives, on the enigmatic relationship between the built and the natural, between the line of the horizon engulfed by the exuberance of the landscape and the vertical axes that appeal to the sky and the depths of the earth. The use of interactive software for graphic restitution, digital representation, the use of photogrammetric techniques and 3D modelling has made it possible to understand and subsequently document the current appearance of the estate, laying the foundations not only for a scientific procedure that can be used on other architectural
Fig. I I.The Quinta

da Regaleira in Sintra, three-dimensional model, zenith view of the Poço Iniciático.

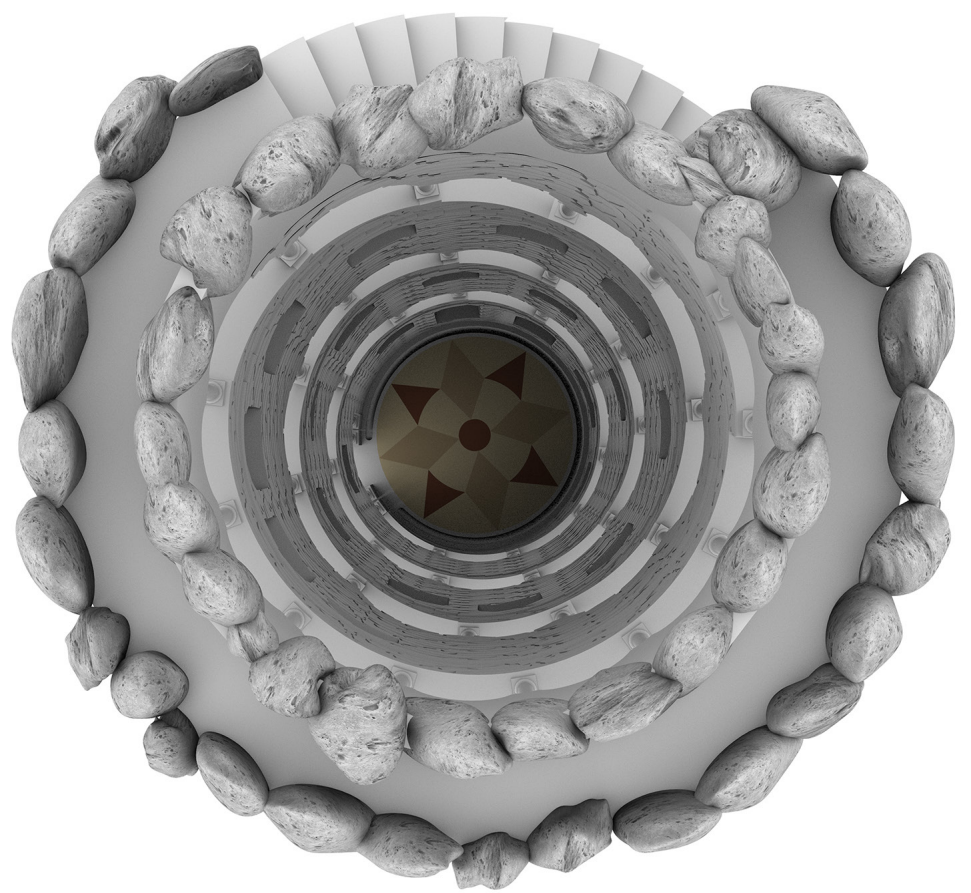




\section{References}

Amoruso G. et al. (20 I I). Realtà, simulazione e progetto. Il ruolo del modello. Santarcangelo di Romagna: Maggioli Editore.

Apollonio F. I. (20I2). Architettura in 3D. Modelli digitali per i sistemi cognitivi. Milano: Bruno Mondadori.

Bertocci S., Parrinello S. (20I5). Digital Survey and Documentation of the Archeological and Architectural sites. UNESCO World Heritage list. Firenze: Edifir edizioni.

Carlevaris L., Filippa M. (a cura di) (20I2). Elogio della teoria. Identità delle discipline del disegno e del rilievo. Atti del IX Congresso dell'Unione Italiana per il Disegno. Roma, 13 - 15 dicembre 2012. Roma: Gangemi Editore.

Corniello L. (2019). Il disegno del Parco Reale di Tirana. Napoli: La scuola di Pitagora editrice.

Docci M., Gaiani M., Maestri D. (20I I). La scienza del Disegno. Milano: CittàStudi.

França J. A. (2004). História da arte em Portugal. O Pombalismo e o Romantismo. Lisbona: Editorial Presença.

Fundação Cultursintra (2006). Quinta da Regaleira, Luigi Manini: imaginário \& método, arquitectura \& cenografia, exposição internacional. Sintra: Fundação Cultursintra.

Gaiani M. (20|4). Smart City: dal rilievo ex-post al rilievo ex-ante. In M. Unali. Atlante dell'abitare virtuale. II Disegno della Città Virtuale, fra Ricerca e Didattica, pp. I 17- I23. Roma: Gangemi editore.

Giandebiaggi P., Zerbi A. (20 I5). Rilievo metrico e fotogrammetrico. In R. Cadignani. La torre Ghirlandina. Cronaca del restauro e studi recenti, pp. 18-20. Roma: Luca Sossella edizioni.

Giordano P. (20 I6). II disegno dei parchi urbani. In G. M. Cennamo. Processi di analisi per strategie di valorizzazione dei paesaggi urbani, pp. 79-88. Roma: Ermes Editore.

Janeiro P. A. (20।8). O desenho do céu da rua, Tres Metodologias para a Representacao Figurativa da Rua e dos seus Objectos. Lisbona: Chiado Editora.

Luigini A. (2007). Simulare la visione della realtà. Strumenti digitali per la visualizzazione avanzata, Simulating the Vision of Reality. In P.Tunzi. Virtualità del Reale. Dalla misura lineare alla visualizzazione 3D di antiche fabbriche. Roma: Edizioni Kappa.

Martins R. (20 I3). A Mensagem Alquimica da Quinta da Regaleira: Elementos de Alquimia e Esoterismo na Gramática Decoratica da Regaleira. CreateSpace Independent Publishing Platform.

Piccarolo G., Ricci G. (2007). Luigi Manini (1 848-1936). Architetto e scenografo, pittore e fotografo, catalogo della mostra (Crema, 6 maggio-8 luglio 2007). Cinisello Balsamo: Silvana editoriale.

Piga B. E. A., Salerno R. (20 17). Urban Design and Representation. A Multidisciplinary and Multisensory Approach. Cham: Springer International Publishing.

Vitali M. (2010). La rappresentazione tridimensionale in ambito urbano. In C. Boido, D. Coppo. Rilievo urbano. Conoscenza e rappresentazione della città consolidata, pp. | 32- |37. Firenze: Alinea.

\section{Authors}

Gennaro Pio Lento, Università degli Studi della Campania “Luigi Vanvitelli”, gennaropio.lento@unicampania.it Fabiana Guerriero, Università degli Studi della Campania “Luigi Vanvitelli", fabiana.guerriero@unicampania.it Luigi Corniello, Università degli Studi della Campania "Luigi Vanvitelli”, luigi.corniello@unicampania.it Pedro António Janeiro, Universidade de Lisboa, pajaneiro@gmail.com

To cite this chapter. Lento Pio Gennaro, Guerriero Fabiana, Corniello Luigi, Janeiro Pedro António (202I). Linguaggi architettonici ed esoterici per a rappresentazione della Quinta da Regaleira a Sintra/Architectural and esoteric languages for the representation of the Quinta da Regaleira in Sintra. In Arena A., Arena M., Mediati D., Raffa P. (a cura di). Connettere. Un disegno per annodare e tessere. Linguaggi Distanze Tecnologie. Atti de $42^{\circ}$ Convegno Internazionale dei Docenti delle Discipline della Rappresentazione/Connecting. Drawing for weaving relationship. Languages Distances Technologies. Proceedings of the $42^{\text {th }}$ International Conference of Representation Disciplines Teachers. Milano: FrancoAngeli, pp. 859-878. 